\title{
顎骨霣胞壁の赤外線吸収スペクトル
}

鈴 木 貢

\section{Infrared spectroscopic investigation on cysts wall of the jaws}

\author{
Mitsugu SuzukI
}

\section{I 緒論}

顠，口腔領域には，篗胞性の疾患 ${ }^{1 \sim 3)}$ が多々みられる. したがって，顎，口腔跣胞に関する報告は，従来から多 くなされているが4-6)，主に個々の症例報告であり，病 理組織学的考察を中心にしたるのであっだ 11)、顎，口

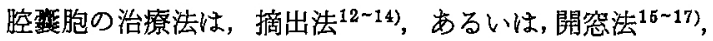
など種々の試みがなされると共に，内容液中に跈離され た細胞で竬胞の種類の診断に応用され始めているので18),

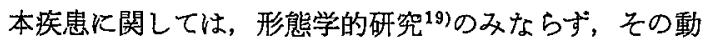
態化学的知見が必要である. しかし, 售胞内容液の生化 学的考察はきわめて少なく, 吉田 ${ }^{20)}$ Toller $^{21)}$, Vicke-

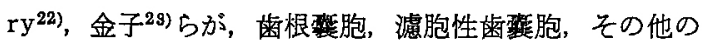
整胞および堡胞性ニナメル上皮腫，などの蛋白質，コレ ステリン 24,25)，糖質 ${ }^{26)}$ ，電解質， $2 \sim 3$ の酵素活性 ${ }^{27 ~ 29)}$ に関する比較を報告しているにすぎず，未だ総合的知見 に乏しい.

そこで著者は，血清，垔胞壁，内容液の相関に関し， 特に銮胞壁の透過性を中心に臨床生化学的考察を別報で 報告したが30,31)，この問題を論ずるには，殬胞壁の化学 組成が関係するものと考觉，赤外線吸収スペクトル解析 法を応用して組成解析を行なったところ，歯根雚胞，濾

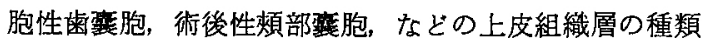
の違いにより，組織成分に差異のあることが判明したの で，その結果を報告する.

\section{II 方}

法

1. 測 定 資 料

整胞壁は，表 1 に示した症例の摘出したるのを，ただ ちに凍結脱水乾燥したのち，メノウの乳鉢と乳棒により 粉末にして，デシケーター内で乾燥して試料とした．対

弘前大学医学部附属病院齿科口然外科

(主任：鈴木 貢 助教授)

Clinic of Dentistry and Oral Surgery, Hirosaki University, School of Medicine

(Chief : Ass. Prof. Mitsugu Suzuki)

受付 昭和 47 年 11 月 30 日
照資料は，正常歯肉拈よび齿小霍を用い，上述の方法に より試料にした，これらの試料と同一の資料は，摘出と 同時に10\%中性ホルマリンに潰け，常法にしたがって， 病理標本を作製した。

2. 測 定 方 法

試料は， $\mathrm{KBr}$ と混合し，Disk を作り，測定に供した。 測定器は, 日本分光工業製601 $S$ 型, 及び IRA-2 型 により $4,000 \mathrm{~cm}^{-1} \sim 200 \mathrm{~cm}^{-1}, 4,000 \mathrm{~cm}^{-1} \sim 400 \mathrm{~cm}^{-1}$ の 範囲の透過吸收を測定した。

\section{III 結 果}

1. 歯 根 亯 胞

歯根垉壁の病理組織像は，症例 R-3 の所見では，

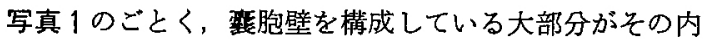
層にあたり，数骆の重層扁平上皮で被覆され，その直下 の肉芽組織層には，細胞浸潤が諗められず，毛細血管の 抬張水腫像がみられ，さらに外層に結合織増成による線 維化像を示している. 他の症例むほぼこの所見に類する 像であった。

齿根朢胞壁の示す赤外線吸収スペクトルは，図１に示

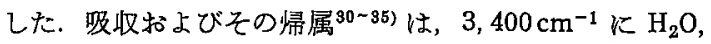
$2,930 \mathrm{~cm}^{-1}$ 飞 $\mathrm{CH}_{2}, 1,640 \mathrm{~cm}^{-1}$ に CO(amid I), 1,530 $\mathrm{cm}^{-1} K-\mathrm{NH}$ (amid II), $1,445 \mathrm{~cm}^{-1} k \mathrm{CH}_{3}, 1,400$

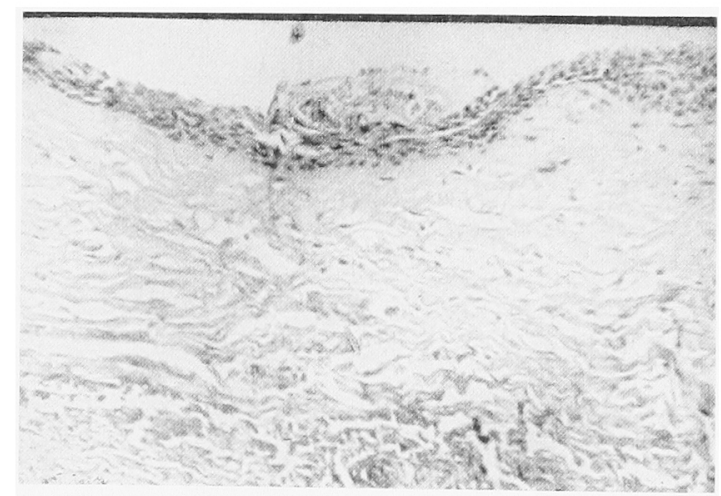

写真 1 歯根独胞壁 (R-3) 


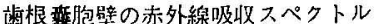

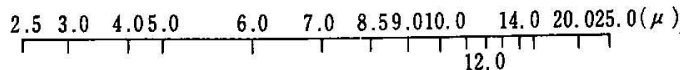

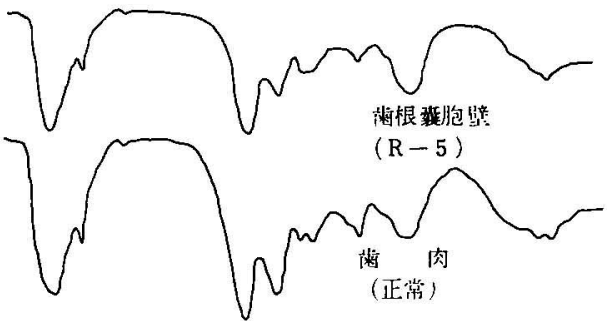

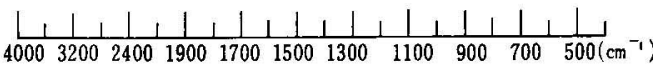

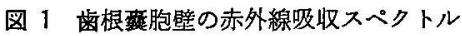

$\mathrm{cm}^{-1} K \mathrm{COO}-1,235 \mathrm{~cm}^{-1} k \mathrm{P}-\mathrm{O}, 1,150 \mathrm{~cm}^{-1} \mathrm{~K}$ コレスリンェステル $1050 \mathrm{~cm}^{-1} k-\mathrm{OSO}_{3} \mathrm{H}, 700 \mathrm{~cm}^{-1}$ と $560 \mathrm{~cm}^{-1}$ に $\mathrm{PO}_{4}$ の吸収を示した。 これらの吸収は, 5 症例とすに共通していた.

正常歯肉は， $3,400 \mathrm{~cm}^{-1}$ の $\mathrm{H}_{2} \mathrm{O}$ の吸收がややブロー ドになっている外は，電根軎胞壁の示す吸収と全て同じ 吸収括よび吸收強度を示した。

\section{2. 濾胞性歯重胞}

滤胞珄歯藮胞壁の病理組織像は，症例 D-4 の所見で は，写真 2 のごとく，壁の内面の組織は数層の扁平上皮 層と粗な結合組織層とにより構成されている像を示して いる．他の症例むほぼ類似した所見である。

濾胞性雷栾胞壁の示す赤外線吸収スペクトルは，図 2

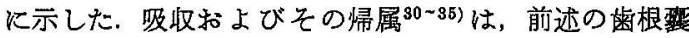
胞壁の示す吸収和よび吸収強度とほとえど同じ状態であ る.こ礼らの吸収は各症例とす共通していた。

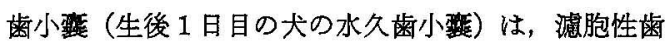
変胞の示す 1, $050 \mathrm{~cm}^{-1}$ の吸収がややブロードで， 1,040 $\mathrm{cm}^{-1}$ に移り，1,150 $\mathrm{cm}^{-1}$ の吸収がはなはた弱くなった 外は，濾胞珄霜萑胞の示す吸収と全て同じ吸収および吸

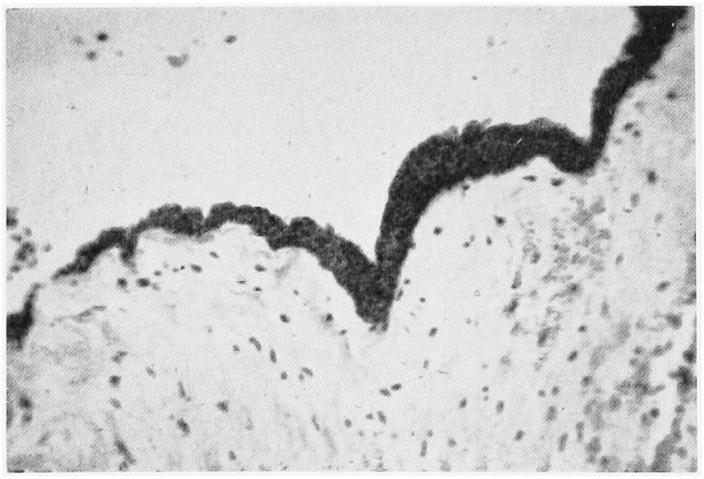

写真 2 濾胞性粦垔胞 (D-4)

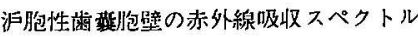

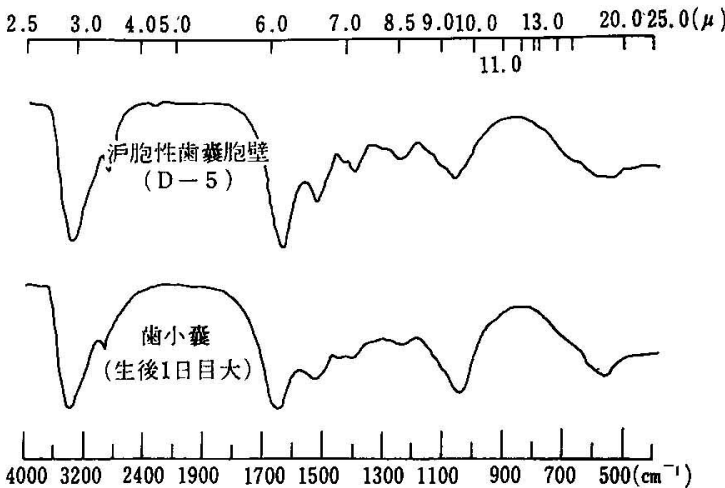

図 2 源胞性歯萁胞壁の赤外線吸収スペクトル

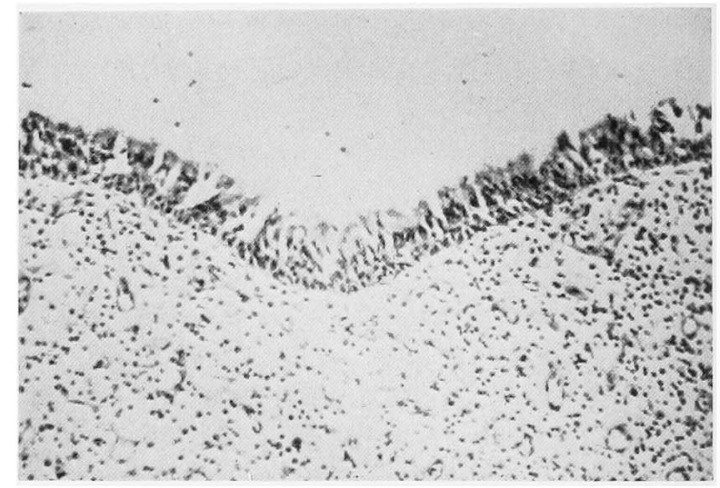

写真 3 術後性頓部霆胞壁一縅毛上皮一( P-9)

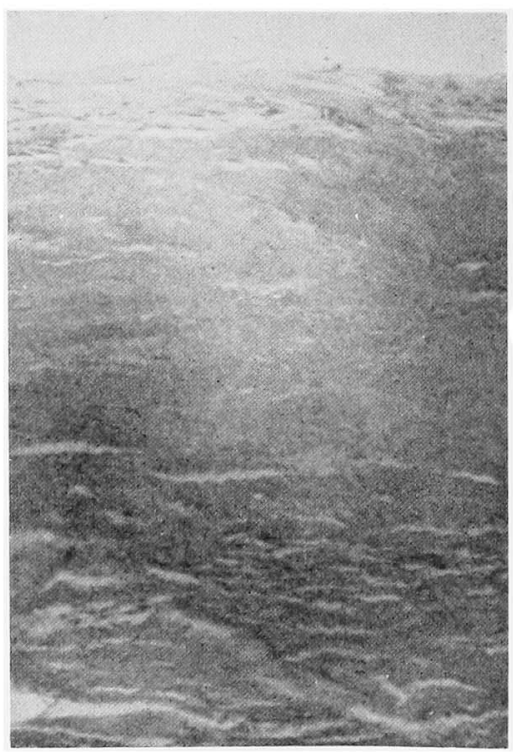

写本 4 術後性煩部唯胞壁一上皮層欠一 ( P - - ) 


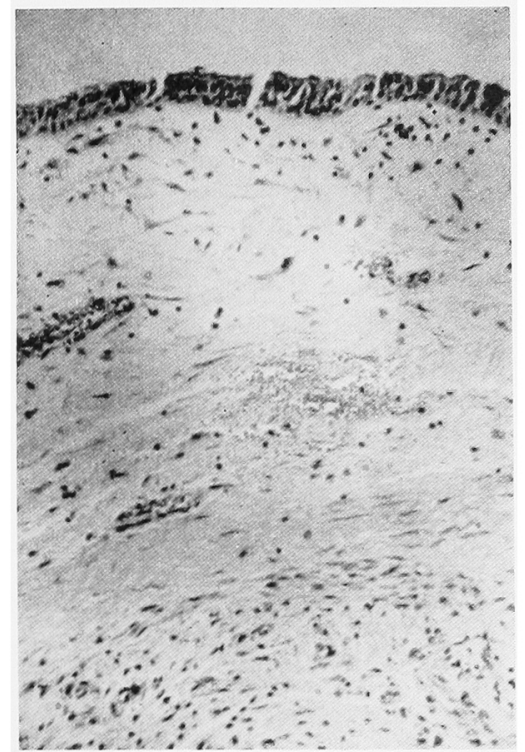

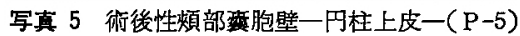

収強度を示した。しかるこれらの吸収は，生後1日目の 犬の乳歯歯小鈤胞も同じ状態を示した。

\section{3. 術後性頓部霆胞}

術後性頓部雚胞壁の病理組織像は, 繊毛上皮層を有す る場合には, (症例 P-2, P-9, P-10), 症例 P-9 の所

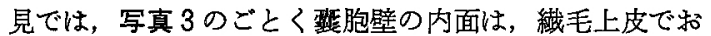
おわれ，その外層は浮腫性の肉芽組織よりなり, Plasmazellen を主とした小円形細胞の浸潤を認める像を示 している.

上皮層を欠く場合には（検索症例 P-3, P-4, P-7）， 症例P-3の所見では, 写真 4 のごとく, 標本内に内皮細 胞が存在せず，硝子化した肉芽組織と炎症性細胞浸潤の

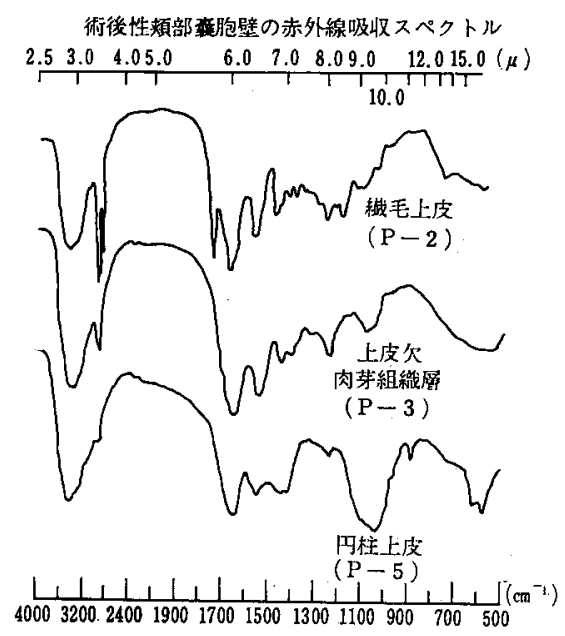

図 3 術後性煩部薥胞壁の赤外線吸収スペクトル
認められる慢性炎症像を示している.

円柱上皮層を有する場合には，症例 P-5の所見では， 写真 5 のごとく，韲胞内面は，円柱上皮でお括われてい て，外層は，線維性の肉芽組織層から成っているが，炎 症像の認められない像を示している.

術後性頓部翼胞壁の示す赤外線吸収スペクトルは，図 3に示した．㵶毛上皮の場合には，吸収括よび帰属30 35) は, $3,400 \mathrm{~cm}^{-1}$ K $\mathrm{H}_{2} \mathrm{O}, 3,080 \mathrm{~cm}^{-1} k \mathrm{NH}, 2,935 \mathrm{~cm}^{-1}$ に $\mathrm{CH}_{2}, 2,855 \mathrm{~cm}^{-1}$ に $\mathrm{CH}_{2}, 1,740 \mathrm{~cm}^{-1}$ に脂肪酸 $(-\mathrm{C}$ $\mathrm{OOH}$ ), $1,660 \mathrm{~cm}^{-1} に \mathrm{CO}$ (Amid I), $1,550 \mathrm{~cm}^{-1} に$ $\mathrm{NH}$ (Amid II), $1,460 \mathrm{~cm}^{-1}$ に $\mathrm{CH}_{3}, 1,400 \mathrm{~cm}^{-1}$ K $\mathrm{COO}-, 1,380 \mathrm{~cm}^{-1}$ K $\mathrm{CH}_{3}, 1,340 \mathrm{~cm}^{-1} に-\mathrm{SO}_{2-}$, $1,282 \mathrm{~cm}^{-1}, 1,242 \mathrm{~cm}^{-1} K \mathrm{P}-\mathrm{O}, 1,200 \mathrm{~cm}^{-1} \mathrm{~K}-\mathrm{OSO}_{3} \mathrm{H}$, $1,150 \mathrm{~cm}^{-1}$ にコレステリンエステル, $1,118 \mathrm{~cm}^{-1}$ に $\mathrm{NH}_{3^{-}}, 1,085 \mathrm{~cm}^{-1}$ に燐脂質, $1035 \mathrm{~cm}^{-1} k \mathrm{P}-\mathrm{OH}, 975$ $\mathrm{cm}^{-1} k{ }^{\mathrm{H}}>\mathrm{C}=\mathrm{C} く_{\mathrm{H}}$ トランス型, $725 \mathrm{~cm}^{-1} k \mathrm{CH}_{2}$ の 吸収を示した。

上皮層を欠く場合には，その吸収および州属 ${ }^{30-35) は ， ~}$ $3,400 \mathrm{~cm}^{-1}$ K $\mathrm{H}_{2} \mathrm{O}, 3,080 \mathrm{~cm}^{-1}$ に NH, $2,935 \mathrm{~cm}^{-1}$ に $\mathrm{CH}_{2}, 1,650 \mathrm{~cm}^{-1}$ K CO (Amid I), $1,540 \mathrm{~cm}^{-1}$ K NH (Amid II), $1,400 \mathrm{~cm}^{-1} に \mathrm{COO}-, 1,340 \mathrm{~cm}^{-1} k-\mathrm{SO}_{2-}$. $1,240 \mathrm{~cm}^{-1}$ に $\mathrm{P}-0,1,160 \mathrm{~cm}^{-1}$ にコレステリンェステ ル，1,080 $\mathrm{cm}^{-1}$ に燐脂質の吸収を示した. $600 \mathrm{~cm}^{-1}$ 附 近には、ブロードな $\mathrm{PO}_{4}$ の吸収を示した。

円柱上皮を有する場合には，3,400 $\mathrm{cm}^{-1} k \mathrm{H}_{2} \mathrm{O}$ の吸 収を，3,080 $\mathrm{cm}^{-1}$ に $\mathrm{NH}, 2,935 \mathrm{~cm}^{-1}$ k $\mathrm{CH}_{2}$ の吸収 のショルダーを示した. $1,650 \mathrm{~cm}^{-1}$ と CO (Amid I), $1,550 \mathrm{~cm}^{-1} に \mathrm{NH}$ (Amid II), $1,450 \mathrm{~cm}^{-1}$ に $\mathrm{CH}_{3}$, $1,420 \mathrm{~cm}^{-1}$ K $\mathrm{CH}_{2}, 1,340 \mathrm{~cm}^{-1}$ K $\mathrm{SO}_{2}^{-}, 1,240 \mathrm{~cm}^{-1}$ k P $-0,1,110 \sim 1,030 \mathrm{~cm}^{-1}$ k $\mathrm{PO}_{4}, 885 \mathrm{~cm}^{-1}$ に糖質 $>\mathrm{C}=0,610 \mathrm{~cm}^{-1}, 570 \mathrm{~cm}^{-1}$ 飞 $\mathrm{PO}_{4}$ の吸収を示した.

円柱上皮層の示す吸収は，ほ注扁平上皮層の示す吸収に 類似していたが，織毛上皮層掞よび上皮層を久く場合に は，円柱上皮層の示す吸収とは異なる吸収を有する。

\section{IV 考察}

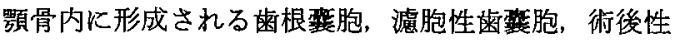
頓部㟟胞は，表 2 に示すよらに，それぞれ病理発生が異 なるが，翼胞壁は，共に上皮系組織層を有する(9)。この

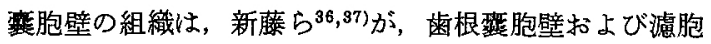
性劉胞壁の重層扁平上皮, 術後性頓部壁胞壁の円柱上皮 を電䫓レベルで観察した結果, 重層扁平上皮执よび円柱 上皮の表層細胞には，多数の microvilli 様突起を有し， 細胞間結合は， desmosomeにより，その数が少なく， 疎な細胞間隙である，細胞質には，r-ER (endoplasmic reticulum), Golgi 体が良く発達し, mitochondria, 遊 離の ribosome, 分泌顆粒, lysosome 様顆粒がみられる. 基底細胞には，大きな核，多数の mitochondria， r-ER, Golgi 体, 遊離の ribosome, lysosme 様顆粒がみðられ 
表 1 検 索 症 例

\begin{tabular}{|c|c|c|c|c|}
\hline 種類 & 症 例 & 性年令 & 部位, 大きさ & 車胞壁の病理組織 \\
\hline $\begin{array}{l}\text { 歯 } \\
\text { 根 } \\
\text { 亚 } \\
\text { 胞 }\end{array}$ & $\begin{array}{l}R-1 \\
R-2 \\
R-3 \\
R-4 \\
R-5\end{array}$ & $\begin{array}{ll}\text { 우 } & 46 \\
\text { 个ै } & 58 \\
\text { 우 } & 61 \\
\text { 个 } & 39 \\
\text { 个 } & 48\end{array}$ & $\begin{array}{l}3\rfloor \text { 部, 拇指頭大 } \\
3 \text { 部, 鳩卵大 } \\
\text { 左側下額骨全域 } \\
\frac{2}{2} \text { '部, 鳩卵大 } \\
543 \text { 部, 鳩卵大 }\end{array}$ & $\begin{array}{l}\text { 重層扁平上皮 } \\
\text { 重層扁平上皮 } \\
\text { 重層扁平上皮 } \\
\text { 重層扁平上皮 }\end{array}$ \\
\hline $\begin{array}{l}\text { 沪 } \\
\text { 胞 } \\
\text { 性 } \\
\text { 歯 } \\
\text { 意 } \\
\text { 胞 }\end{array}$ & $\begin{array}{l}D-1 \\
D-2 \\
D-3 \\
D-4 \\
D-5\end{array}$ & $\begin{array}{ll}\text { 우 } & 17 \\
\text { 이 } & 31 \\
\text { 우 } & 45 \\
\text { 우 } & 30 \\
\text { 우 } & 68\end{array}$ & $\begin{array}{l}\text { 左側下䫛角部, 鳩卵大 } \\
\sqrt{6} \sim \text { 上行枝全域 } \\
13 \text { 部, 鳩卵大 } \\
\text { 上類正中, 鳩卵大 } \\
\text { 右側下䝷骨全域 }\end{array}$ & $\begin{array}{l}\text { 重層扁平上皮 } \\
\text { 上皮委縮性,硝子化結合組織 } \\
\text { 上皮層欠, 肉芽組織層 } \\
\text { 重層扁平上皮 } \\
\text { 重層扁平上皮 }\end{array}$ \\
\hline $\begin{array}{l}\text { 術 } \\
\text { 後 } \\
\text { 性 } \\
\text { 頼 } \\
\text { 部 } \\
\text { 衰 } \\
\text { 胞 }\end{array}$ & $\begin{array}{l}P-1 \\
P-2 \\
P-3 \\
P-4 \\
P-5 \\
P-6 \\
P-7 \\
P-8 \\
P-9 \\
P-10\end{array}$ & $\begin{array}{ll}\hat{\delta} & 41 \\
\text { } & 57 \\
\text { } & 38 \\
\text { } & 51 \\
\text { } & 51 \\
\text { } & 51 \\
\text { ㅇ } & 44 \\
\text { + } & 59 \\
\text { ᄋ } & 28 \\
\text { 个 } & 51 \\
\text { ᄋ } & 51\end{array}$ & 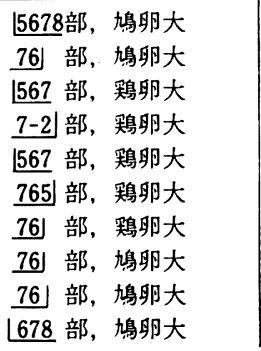 & $\begin{array}{l}\text { 械毛上皮 } \\
\text { 上皮層欠, 肉芽組織層 } \\
\text { 上皮層欠, 肉芽組織層 } \\
\text { 円柱上皮 } \\
\text { 重層扁平上皮 } \\
\text { 上皮層欠, 肉芽組織層 } \\
\text { 重層扁平上皮 } \\
\text { 伡毛上皮 } \\
\text { 織毛上皮 }\end{array}$ \\
\hline
\end{tabular}

表 2 賈胞の発生と序機病理組織像比較

\begin{tabular}{|c|c|c|}
\hline 種 & 病 理 発 生 & 病 理 形 態 \\
\hline 歯 根 戴 胞 & 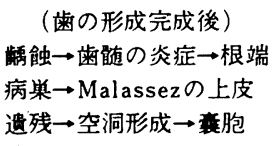 & $\begin{aligned} & \text { 内層: }: \text { 上皮層 } \rightarrow \text { 主として } \text { 重層扁平上皮 } \\
& \text { 外層 : } \text { 肉芽組織層 } \\
& \text { 結合組織層 }\end{aligned}$ \\
\hline 沪胞性歯咅胞 & $\begin{array}{l}\quad \text { (歯の形成後期） } \\
\text { エナメル上皮と歯冠との } \\
\text { 間に戠胞 }\end{array}$ & 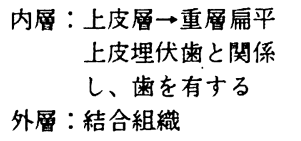 \\
\hline 術後性㚘部嚄胞 & $\begin{array}{c}\text { （上頻洞炎根治手術後） } \\
\text { 術後の㾌痕組織内に発生 }\end{array}$ & $\begin{aligned} & \text { 内層: } \text { 上皮層 } \rightarrow \text { 扁平、円柱 } \\
& \text { 織毛上皮あるいは上 } \\
& \text { 皮を久くことがある } \\
& \text { 外層 : 結合組織 }\end{aligned}$ \\
\hline
\end{tabular}

この細胞膜の中には，細胞質と核質を含む．原 形質には，水，蛋白質 $(\mathrm{CO} \cdot \mathrm{NH}-1650,1550$ $\left.\mathrm{cm}^{-1}\right)$, 脂質 $(-\mathrm{COO}, \mathrm{COOH})$, その他の有機 質，無機イオンを含む．また，細胞の外には， 糖質 $\left(-\mathrm{OH},>\mathrm{C}=0,1,710 \mathrm{~cm}^{-1}\right)$ がある。こ れらの上皮細胞の細胞間接触部位には, 特殊な 膜構造が存在し, junction complex といらと されている40)，これらの上皮組成層の下層には， 結合組織層があるが ${ }^{19)}$ ，結合組織は一般に，実 質細胞（間葉組織の細胞）と細胞間物質とより

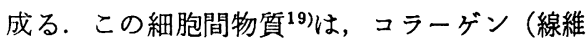
性蛋白質, $1,660 \mathrm{~cm}^{-1}$ )，ムコイド（多糖類，糖 と蛋白質複合体，糖には，(1) hexosomine，六

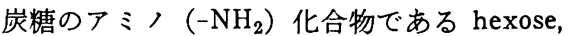

(2) 酸性の多糖類一硫酸基 $-\mathrm{OSO}_{3} \mathrm{H} \cdots \cdots$....ント

るが, r-ER, Golgi 体は歯根隹胞壁の細胞ではよく発 達し, 濾胞性菌整胞壁打よび術後性煩部褧胞壁の細胞で は発達かよくなかった。と述べ，これらのことからみて， 襄胞を形成する上皮細胞は，ER，Golgi 体で特徵づけ られ，活発な分泌活動を営んでいることがらかがわれる としている.

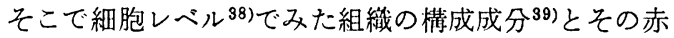
外吸収スペクトルによる特性吸収帯をみると，細胞膜は 一般に脂質, 蛋白質, 水分とから構成され，脂質は，リ ン脂質， $1,235 ， 1,085 \mathrm{~cm}^{-1}$ ，コレステロール，1,739， $1052 \mathrm{~cm}^{-1}$, 蛋白質は, 球状蛋白 $1,637 \mathrm{~cm}^{-1}$, 線維蛋白 $1,660 \mathrm{~cm}^{-1}$, 水分 $3,400 \mathrm{~cm}^{-1}$ の成分を有するとされる.
ロイチン硫酸，セアルロン酸，カルボキシル基 $-\mathrm{COOH}$ (3) 中性の多糖類一，一般に蛋白質と強く結合，などを 含み、これらの物質が網状構造をなしているとされてい る.

これらの組織を細胞の成分ごとに分雄(1)しないで，赤 外線吸収スペクトルの測定を行なえば，上皮層および結 合組織層の細胞膜, 細胞質, 核, 細胞間物質の構成成分 全般の吸収が同時に表われることになる.

実際に，形成された垔胞壁の組成について，赤外線吸 収スペクトル解析を行ない，比較してみると，先に述べ たごとく，四1，2，3のよ5に特定のパターンをもっ た吸収を示した．これらの吸収を総合してみると，表 3 
表 3 蔪胞壁の赤外線吸収スペクトル吸収带

\begin{tabular}{|c|c|c|c|c|c|}
\hline 試料 & 歯根踑胞壁 & $\begin{array}{l}\text { 胒胞性 } \\
\text { 歯胞壁 }\end{array}$ & 術 後 & 生 頛 部 & 胞 \\
\hline 帰属 & 扁平上皮層 & 扁平上皮層 & 繊毛上皮層 & $\begin{array}{c}\text { 上皮層欠 } \\
\text { 肉芽組織層 }\end{array}$ & 円柱上皮層 \\
\hline & $\mathrm{cm}^{-1}$ & $\mathrm{~cm}^{-1}$ & $\mathrm{~cm}^{-1}$ & $\mathrm{~cm}^{-1}$ & $\mathrm{~cm}^{-1}$ \\
\hline $\mathrm{H}_{2} \mathrm{O}$ & 3400 (VS) & 3400 (VS) & 3400 (VS) & 3400 (VS) & 3400 (VS) \\
\hline $\mathrm{N} \mathrm{H}$ & - & - & $3080(\mathrm{sh})$ & $3080(\mathrm{sh})$ & $3080(\mathrm{sh})$ \\
\hline $\mathrm{C} \mathrm{H}_{2}$ & $2930(\mathrm{~S})$ & $2930(\mathrm{~S})$ & 2935(VS) & $2935(\mathrm{~S})$ & $2935(\mathrm{sh})$ \\
\hline $\mathrm{CH}_{2}$ & - & - & 2855 (VS) & - & - \\
\hline$-\underset{\text { 脂肪酸 }}{\mathrm{C}}$ & - & - & 1740 (VS) & - & - \\
\hline$-\mathrm{CO}$ amid I & $1640(\mathrm{~S})$ & $1640(\mathrm{~S})$ & 1660 (VS) & 1650 (VS ) & 1650 (VS) \\
\hline NH amid II & $1530(\mathrm{~S})$ & $1530(\mathrm{~S})$ & $1550(\mathrm{~S})$ & 1540 (VS) & $1550(\mathrm{~S})$ \\
\hline $\mathrm{CH}_{3}$ & $1445(\mathrm{~m})$ & $1450(\mathrm{~m})$ & $1460(\mathrm{~S})$ & - & $1450(\mathrm{~m})$ \\
\hline $\mathrm{COO}-$ & $1400(\mathrm{~m})$ & $1400(S)$ & $1400(S)$ & $1400(\mathrm{~S})$ & $1420(\mathrm{~m})$ \\
\hline $\mathrm{CH}_{3}$ & - & - & $1380(\mathrm{~m})$ & - & \\
\hline$-\mathrm{SO}_{2}-$ & - & - & $1340(\mathrm{~m})$ & $1340(W)$ & $1340(\mathrm{~W})$ \\
\hline$P-O$ & $1235(\mathrm{~m})$ & $1235(\mathrm{~m})$ & $1240(\mathrm{~S})$ & $1240(\mathrm{~m})$ & $1240(\mathrm{~m})$ \\
\hline & - & - & $1200(\mathrm{sh})$ & - & - \\
\hline $\begin{array}{l}\text { コレスデル } \\
\text { シエステル }\end{array}$ & $1150(\mathrm{sh})$ & $1150(\mathrm{sh})$ & $1150(\mathrm{~S})$ & $1160(W)$ & - \\
\hline $\mathrm{NH}_{3}$ & - & - & $1118(\mathrm{~m})$ & - & $1118(W)$ \\
\hline 燐脂睤 & - & - & $1085(\mathrm{~m})$ & $1080(\mathrm{~S})$ & - \\
\hline$-\mathrm{OSO}_{3} \mathrm{H}>$ & $1050(\mathrm{~S})$ & $1050(\mathrm{~S})$ & - & - & - \\
\hline $\mathrm{P}-\mathrm{OH}$ & - & - & $1035(\mathrm{sh})$ & - & $1030(\mathrm{~S})$ \\
\hline $\mathrm{H}_{>} \mathrm{C}=\mathrm{C}<\mathrm{H}$ & - & - & $975(\mathrm{sh})$ & - & - \\
\hline$>\mathrm{C}$ 糖 $=$ 啠 & - & - & - & - & $885(\mathrm{~m})$ \\
\hline $\mathrm{CH}_{2}$ & - & $700(\mathrm{~W})$ & $725(\mathrm{~W})$ & - & - \\
\hline $\mathrm{PO}_{4}$ & $600(\mathrm{~m})$ & $600(\mathrm{~m})$ & - & $600(S)$ & $610(\mathrm{~S})$ \\
\hline $\mathrm{PO}_{4}$ & $560(\mathrm{~m})$ & $560(\mathrm{~m})$ & - & $600(\mathrm{~S})$ & $570(\mathrm{~S})$ \\
\hline
\end{tabular}

V; Very, S; Strong, W; Weak, Sh; shalder, m; medium

のごとく，扁平上皮層を有する壁は，きわめてよく似た 吸収扰よび吸收強度を示すが，㵶毛上皮層を有する壁 ${ }^{42)}$, あるいは上皮層を欠く肉芽組織層の壁 ${ }^{42}$ は，扁平上皮層 の壁々, 3, 080 2, $855 \mathrm{~cm}^{-1}, 1,940 \mathrm{~cm}^{-1}, 1,282 \sim 1,000$ $\mathrm{cm}^{-1}, 900 \sim 600 \mathrm{~cm}^{-1}$ の範囲の吸収が全たく異なってい る. したがって重層扁平上皮, 肉芽組織層, 㵶毛上皮層, 円柱上皮層相互では，構成成分のうち $\mathrm{NH},-\mathrm{COOH}$, $\mathrm{NH}_{3}, \mathrm{PO}_{4}$ に差異がある(すなわち, mucoid が多いこ とを意味している）ものと判断する．金子'23) は琵胞溶液 の諸検索の結果, hexoamine 量は他の擎胞に比べ, 術 後性煩部喃胞が最も高い值を示したことは，褧胞の上皮 細胞からの分泌も内容液の一部を構成する可能性を指摘 しているが，本研究では上述のごとく， $\mathrm{NH}, \mathrm{NH}_{3}$ が他

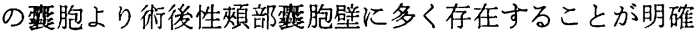
であるので，金子の推定を裏付けているものと思われる

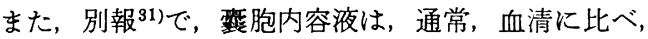
acid phosphatase が高く, 褧胞が感染すると血清に比 べ, alkaline phosphatase が高い值を示し, 感染が消 失すると低下されてくることを述べた．この現象は，上 皮層の物質の移動機序から久て ${ }^{43)}$, 汻胞壁からの酵素の 遊出44)を推定したが，森らの歯肉に批ける phosphatase 活性に関する報告45)で，通常，歯肉上皮に局在しない alkaline phosphatase が感染炎症を起すと出できるよう になるといらことは，锤胞壁の赤外線吸収スペクトルに おいて，扁平上皮層は，歯肉ときわめて類似したパター ンを示すことに関連して，先の推定を裏付けたものと考 える.

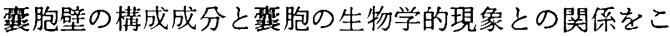
こに $2 \sim 3$ 述べたが，䍂胞の生化学的動態を鮮明してゆ

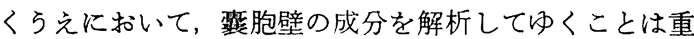
要なことであり，その成績は一つの手がかかりになるも のと考える.さらに閛胞壁の成分をそれぞれに分離 ${ }^{41)}$ て，検討してゆくことが必要であると思われるが，本報 では，その基礎となるべき成績を報告した。

\section{V 結論}

䫇骨㤠胞のうち, 臨床所見, X線写真診断, 病理組織 診断で病名の確定している料根整胞 5 例, 濾胞性歯整胞 5 例, 術後性露胞10例について，耎胞壁の赤外線吸収ス ペクトル解析を行ない，次の知見を得た。

1）歯根裂胞壁之濾胞性歯裂胞壁の重層扁平上皮は, 歯肉，扣よび歯胚の歯小悂にきわめて類似した吸収を示 す.

2）術後性煩部㖶胞の繊毛上皮は，歯肉と異なる吸収 
を示し，上皮層を欠く肉芽組織層は，歯肉および繊毛上 皮とも巽なる吸収を示すが，円柱上皮は，歯内，あるい は重層平上皮と類似した吸収を示す。

3）扁平上皮, 繊毛上皮, 上皮層を欠く肉芽組織層, 円柱上皮との間の構成成成分の差異は, $\mathrm{NH},-\mathrm{COOH}$, $\mathrm{NH}_{3}, \mathrm{PO}_{4}$ である.

本研究の一部は昭和 47 年 4 月 9 日, 第26回日本口腔科 学会総会に報告した. 要旨は, 昭和 47 年 11 月 12 日, 第 20 回日本口腔科学会, 中四国地方部会に報告した.

\section{文献}

1）上野正, 他分担執筆: 顎, 口腔領域の乑胞. 新編臨床口 肊科学, 医歯薬出版, 東京, 昭43，263面.

2）伊藤秀夫, 中村平蔵監修: 口腔領域の膲胞. 最新口腔外 科学, 医歯薬出版, 東京, 昭46, 39頁,

3）金森虎男原著, 林一改訂 : 落胞. 医歯薬出版, 東京, 昭 47, 307面.

4) Schulte, W. : Die Knochenregeneration nach der Ausschälung großer Kieferzysten und ihre Konsequenzen für die Operationstechnik. Deutsche Zahn Mund-und Kiefer heilkunde Bd. 45, H 5, 177, 206, 1965.

5) Bhaskar, N. : Periapical lesion-types, incidence and clinical features.-Oral Surg Oral Med Oral Path 21 : 657, 1966.

6）伊藤秀夫, 他 : 顎骨変胞の臨床統計的検討(抄). 口科誌 $18: 2411969$

7）藤岡幸堆：各種顎骨蕞胞の観察，特にその成因ならびに 診断に関する知見補遗. 口外誌 $8: 671962$

8）常葉信雄: 䫇骨莛胞とその処置. 歯界展望 $19: 477$ 1962.

9）柴田秀二：術後性上䫟洞虽腫の成因に就いての考察. 日 耳奥 $54: 841950$.

10）内田安信，他：術後性頓部缕胞の臨床的観察，口科誌 $15: 2241966$

11）石泰三，他：演胞性歯牙胞の臨床的钼察. 日本歯科評 論 $350: 16761971$.

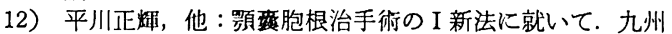
歯科学会雑誌 $13: 3351959$.

13）平川正翚，他：我々の局所自家骨移植，特に上顎葆胞処 理にあたっての着眼点について. 臨床歯科 225:1 1959.

14) Marble, H. B. : Homografts of freeze-dried bone in cystic defects of the jaws. Oral Surg Oral Med Oral Path 26: 1181968.

15）小幡幸男 : 顎骨㫷胞の開空法について。 口病誌 $33: 427$ 1966.

16）西嶋克己，他：わが教室における口腔領域患胞性疾患の 開空術. 口科誌 $18: 5571969$.

17) Saracino, S.F., et all : An unusually large globulomaxillary cyst treated by marsupialization and enucleation. Oral Surg Oral Med Oral Path $25: 298$ 1968.

18) Written, J.B. : Cystologic examination of aspirated material from cysts or cystlike lesions. Oral Surg Oral Med Oral Path. $25: 7101968$.

19）石川梧朗, 他：口哚病理学II. 永末書店, 京都, 1969, 383頁, 840頁, 857頁,
20）吉田滋美 : 顎骨内に発生する罴胞の生成機序に関する生 化学的研究，歯科学報 $67: 971960$.

21) Toller, P. : Origin and Growth of Cysts of the Jaws. Ann R Coll Surg 40:306 1967.

22) Vickery, L.M., Darling, A.I. : An unusual maxillary cyst. Oral Surg Oral Med Oral Path $31: 328$ 1971.

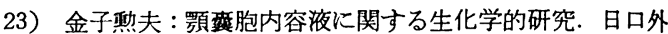
誌 $18: 21972$.

24) Shear, M. : Cholesterol in dental cysts. Oral Surg Oral Med Oral Path 16:1465 1963.

25) Browne, R.M. : The origin of cholesterol in odontogenic cysts in man. Archs oral Biol 16:107 1971.

26) Krikos, G. A. : Histochemical studies of mucin of odontogenic cysts exhibiting mucous metaplasia. Archs oral Biol 11:633 1966 .

27）森昌彦：口腔領域における組織化学. 畨界展望 $23: 709$ 1964.

28) Mori, M., et all : Histochemical obsərvation of enzymes in adenoameloblastoma. Oral Surg Oral Med Oral Path $30: 6591970$.

29) Mori, M. et all : Congenital dermoid cyst of the sublingual region : report of case. Joral Surg 28 : 3661970.

30）鈴木貢，他：口腔底の類皮様索胞の 2 例一その病理像と 内容液の性状について一口科誌 $19: 6381970$ 。

31）鈴木貢：口腔疾患の臨床的考察(第 2 報)，顎・口腔索胞 の臨床生化学的考察. 口科誌, $22: 2103$ 掲载予定

32）鈴木貢, 他 : 歯肉の腫張性疾患一とくに, 赤外線吸収 ペクトルよりみた病理組織の考察— 歯界展望 $32: 843$ 1968.

33）千原吳郎：赤外線吸収スペクトルの医学および生物学へ の応用. 化学の領域, 增刊 31, 南江堂, 東京, 1963, 43頁.

34）平田義正, 他：赤外線分析法. 生物化学最近の進歩, 第 5 集，技報堂，東京，1968，155面.

35）田中誠之，他：赤外吸収スペクトル法一基礎と応用一広 川書店，東京，1970，214.

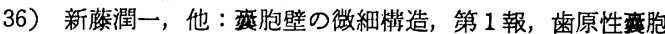
の上皮絶織について(抄)，口科誌 $21: 3891972$.

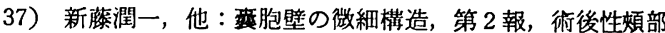
衰胞の円柱上皮について(抄)，第10回日本口腔科学会北 日本地方部会抄録集，1972，17面.

38）山田英智, 他: 細胞の微細臌造, 医人薬人 $21: 31972$.

39）荒谷真平：生化学 (1)（2）（3）歯界展望 $25: 1147$ 1965, $26: 93$ 1965, 26, 231, 1965.

40）荌野義信：上皮細胞の細胞間連絡. 医学のあゆみ 73 : 214 1970, $63: 761,1967$.

41）香川靖雄：膜の生化学的研㶢法. 医学のあゆみ $63: 721$ 1967.

42）岸根克彦, 他: 術後性煩部弯胞の臨床病理学的研究, そ の 2 : 最近経験した29例の病理組織所見について(抄), 口科誌 $21: 3871972$.

43）槚本武則：酵素組識化学の皮膚科領城への応用. いずみ $16: 231969$

44）小坂淳夫, 他 : 肝疾患時の酵素遊出の問題. 医学のあゆ み $63: 8411967$.

45）森昌展，他：口腔粘膜ならびに歯周組紴疾患歯肉に打け る alkaline phosphatase と acid phosphatase に関す る組織化学的研究，口科誌 $9: 239,1960$ 